\title{
Is School Desegregation Still a Viable Policy Option?
}

\section{Citation}

Hochschild, Jennifer. 1997. Is school desegregation still a viable policy option? PS: Political Science and Politics 30, no. 3: 458-466.

\section{Published Version}

http://dx.doi.org/10.2307/420123

\section{Permanent link}

http://nrs.harvard.edu/urn-3:HUL.InstRepos:3347567

\section{Terms of Use}

This article was downloaded from Harvard University's DASH repository, and is made available under the terms and conditions applicable to Other Posted Material, as set forth at http:// nrs.harvard.edu/urn-3:HUL.InstRepos:dash.current.terms-of-use\#LAA

\section{Share Your Story}

The Harvard community has made this article openly available.

Please share how this access benefits you. Submit a story.

\section{Accessibility}


schools than do blacks in the city. Indeed, within the city, blacks' and whites' views of the schools are similar, and the same is true in mixedrace suburban neighborhoods. Only in single-race suburban communities do blacks' and whites' evaluations differ.

Understanding the views of blacks and whites in mixed-race areas, and of black suburbanites generally, is especially important in light of the changing demographics of major cities. The movement of blacks to the suburbs and the slowly declining segregation in major metropolitan areas are important urban trends. The impact of changing residential patterns of blacks and whites is not yet adequately understood, but seems consequential in several ways. Mixedrace neighborhoods promote interracial contact, for example, as well as lower levels of racial solidar- ity among blacks; and interracial contact in turn, promotes more positive attitudes toward members of the other race, at least in some contexts.

Of course, while taking place of residence and school performance into account reduces racial differences in attitudes toward the schools, in the Detroit area most whites live where the schools are performing at least reasonably well, and most blacks live where the schools are not performing that well. Thus, four decades after the seminal events of the 1950s, racial segregation in education continues to play a crucial role in the disparities in well-being of urban black and white populations.

\section{Notes}

1. We had to assign all city residents the overall city MEAP average, since Detroit has a single district and it was impossible to assign building-by-building scores. Thus these data mask variation within the city.

\section{Reference}

Loury, Glenn C. 1997. "Integration Has Had Its Day," New York Times, 23 April.

\section{About the Authors}

Susan Welch is Dean of the College of the Liberal Arts at The Pennsylvania State University.

Michael Combs is associate professor of political science at the University of Nebraska, Lincoln.

Lee Sigelman is professor of political science at The George Washington University.

Timothy Bledsoe is professor of political science at Wayne State University.

\section{Is School Desegregation Still a Viable Policy Option?}

\section{Jennifer Hochschild, Princeton University}

$\mathbf{M}$ andatory school desegregation is not usually seen as a success story. Most citizens and elected officials disfavor it; judges increasingly are withdrawing courts from active involvement in or even oversight of racially mixed school districts; interest groups and educators are focused on other means of addressing problems of racial inequality in schools. Students throughout the United States are at least as racially isolated now as students were two decades ago. ${ }^{1}$

Nevertheless, the history of school desegregation offers useful lessons. To begin with, it can provide object lessons about what not to do in seeking to promulgate and maintain an important social reform. But many policy initiatives could do that. More positively, school desegregation demonstrates a patterned array of significant successes as well as highly visible failures. If we can understand where and why school desegregation occurs, why it has developed in particular directions, and why it has suc- ceeded in some places much more than in others, we will have a better chance of successfully promoting either it or a more popular and effective successor.

\section{The Range of School Desegregation Outcomes}

Some school districts never developed a plan for desegregation of significant numbers of students. Examples include New York City, Hartford, and Newark. Others developed, or had developed for them, elaborate plans that never went into effect or were quickly rescinded (Detroit, Los Angeles, Richmond). Some developed substantial voluntary plans that affected large numbers of students (Yonkers, Seattle, Berkeley). And some had full-scale mandatory desegregation programs that affected thousands of students and faculty that persisted for years (Boston,
Charlotte, St. Louis). Some desegregation plans are still in effect.

Within that array of plans and programs nests another, equally important, array-of educational and social outcomes. In Milwaukee, for example, before the desegregation plan was implemented in 1976, there was an average of $21 \%$ white enrollment in minority children's schools; a decade later, that average had increased to $31 \%$. In Dayton, the interracial exposure index rested at 21 in 1976 , the year before desegregation, and rose to 37 a decade after it. Conversely, in St. Paul, the proportion of whites in the average minority child's school was a high $66 \%$ the year before desegregation in 1973 , but had fallen to $61 \%$ a decade after desegregation was implemented (Rossell 1990, 80-94).

Next, consider the process as well as the substance of racial mixing. In some districts, the buses taking children to school in the first year of a desegregation program were escorted by mobs hurling epithets and rocks; in 
other districts the transition was tense but peaceful. The only systematic study of the relationship between desegregative busing and violence within schools found an inverse relationship - the more busing, the less violence-in high schools but a positive relationship in most types of junior high schools (National Institute of Education 1978, A18-19). Cities such as Rochester and Charlotte treated school desegregation as a matter of civic pride and sought to use their success with its implementation as an inducement to outsiders to move to the area; cities such as Pontiac, Michigan are known to the outside world chiefly for their atrocious handling of the desegregative process.

What happens to children once they are in school matters most of all. And here too variation is the main conclusion. In St. Louis, to cite only a recent and unusually careful study, black students who transferred into predominantly white suburban high schools during the early 1990s made more significant academic gains (compared with their own starting points) than did black students who transferred into specialized and wellfunded city magnet schools. The former group also were more likely to graduate from high school than were students who remained in the city (Lissitz 1994; Clough and Uchitelle 1995, 38). Across a sample of eight magnet school programs, "higher financial investments ... were associated with higher levels of integration and educational quality" (Blank 1983, 136-40).

Even public opinion is more varied on the issue of school desegregation than it is commonly thought to be. All surveys show that a huge majority of Americans favor the concept of school desegregation. Twothirds agree more concretely that integration has "improved the quality of education for blacks" and twofifths say the same about the quality of education for whites. Recently, over half of whites and over $80 \%$ of blacks agreed that desegregative efforts should be intensified (Edmonds 1994). More concretely still, an annual national survey of first-year college students-who, after all, have direct experience with school desegregation-shows steady and unvarying increases in support. Between
1976 and 1992 (the first and last years that the question was asked), the proportion of freshmen who agreed that "busing is $\mathrm{OK}$ if it helps to achieve racial balance in the schools" rose from $37 \%$ to $55 \%$ (Cooperative Institutional Research Program 1991, 121-25; 1992, 26).

As the student survey suggests, the framing of a question on a controversial topic makes a considerable difference in proffered opinions on surveys. When presented with the simple option of agreeing that "forced busing" is undesirable, most adult Americans (of all races) take it. But more nuanced questions evoke more ambivalent views. In July 1996 , for example, $43 \%$ of white and $66 \%$ of black residents of Connecticut favored the state Supreme Court's recent ruling that "it was up to the governor and legislature to come up with a plan to improve this [racial] balance" between Hartford and surrounding suburbs. Half of the respondents agreed that "more should be done to integrate schools throughout the state of Connecticut"; three-fifths agreed that racial imbalance is a serious problem; and three-fifths agreed that political officials should "do their best to improve racial integration even if that means doing more than the Court requires," rather than "try[ing] to figure out the smallest change the court will accept" (Frahm 1996a, A1). The dreaded words "forced busing" did not appear in any of these questions, so this support may evaporate. ${ }^{2}$ But it is not a bad platform from which to start pursuing desegregative reforms.

Even the experience of desegregation-related busing does not necessarily produce revulsion. In 1978 and again in 1989, about three-fifths of both white and black parents whose children had been bused for desegregative purposes reported that the experience had been "very satisfactory" (Harris and Associates 1978, $38 ; 1989,116,210)$. There is a problem of self-selection here, of course; some of the people most opposed to busing presumably withdrew their children from the public school system and thus were not among potential respondents to these questions. Nevertheless, it is probably safe to say that none of the white and few of the black respondents would have chosen before the fact to have their child bused, so the finding that almost two-thirds of them were "very" pleased with the experience is a powerful indicator that experience can change preferences.

I could continue-outcomes vary in such arenas as levels of interracial friendship, community involvement with schools, housing and job consequences for desegregated students, pedagogical innovations, desegregation of faculty and administrators, and so on. But my purpose here is more analytic than descriptive, so let us turn to lessons that we can draw from our nation's experience with school desegregation.

\section{Explaining the Variation in Amounts of School Desegregation}

First and most crucially, there would have been no school desegregation absent authoritative imposition from an agent outside and "above" the school districts themselves. ${ }^{3}$ This point begins with Brown v. Board of Education in 1954 and continues through the famous $\mathrm{Su}$ preme Court cases of the succeeding two decades-Green v. New Kent County (1968), Alexander v. Holmes County (1969), Swann v. CharlotteMecklenberg (1971), and Keyes v. Denver (1973). It continues further with a recognition that what the $\mathrm{Su}$ preme Court gives, the Supreme Court takes away; more recent decisions such as Milliken v. Bradley $(1974)^{4}$, Oklahoma v. Dowell $(1991)^{5}$, and Missouri v. Jenkins $(1995)^{6}$ have done almost as much to slow or halt the process of mandatory school desegregation as the string of earlier decisions did to strengthen it.

The point can also be made by starting from the other direction, with a list of school districts and the agents responsible for their initiation of desegregation. Most of the largest districts, or the districts that contain the largest numbers of African American children, were desegregated by court order if at all. A few were desegregated by pressure or requirements from their state board of education, and another few were desegregated by orders from what 
was then the U.S. Department of Health, Education, and Welfare.

Local school boards did institute desegregation plans in a few cities; do they offer an alternative model to the claim just made? One set of such districts include Berkeley, Austin (Texas), and Princeton-which constitutes a large share of the liberal, wealthy, small, predominantly white, highly-educated university towns that are relatively responsive to demands for racial equity. Another group of such districts offers more promise for a claim that authoritative imposition is not necessary; Portland (Oregon), Tacoma (Washington), Racine (Wisconsin), and Rochester (New York) all desegregated as a consequence of school board initiatives. These districts are similar to university towns in that they are relatively small, wealthy, and predominantly white, but at least they resemble other cities more than do Princeton or Berkeley. So perhaps there is an important caveat to my claim of the need for authoritative imposition.

But this caveat loses much of its force on closer inspection. Most cities that chose to desegregate absent a court order in fact chose to desegregate before a court order; they were either directly threatened with a law suit (or administrative order) or they anticipated that a suit might soon be forthcoming. Without such a threat or anticipation, the impetus to desegregate seldom developed, was dissolved, or was bowled over by the opposition. For example, in 1976, the school board of Yonkers responded to pressure from the state Commissioner of Education and rumblings from the local NAACP chapter by hiring a new superintendent with desegregative experience. He promptly set up a community task force to design a plan, and formulated his own program for needed school closings partly on the basis of their desegregative impact. Within a year, however, Commissioner Ewald Nyquist had been fired by an increasingly anti-busing Board of Regents, the mayor of Yonkers continued to replace activist liberals on the local school board with strong conservatives, and local groups were pointing out that the pressure for desegregation had been removed. (As the Taxpayers of Northeast Yonkers put it in a public memo to its members, "It is clear that busing for integration purposes is out of favor even at the state level, and that there is very little likelihood

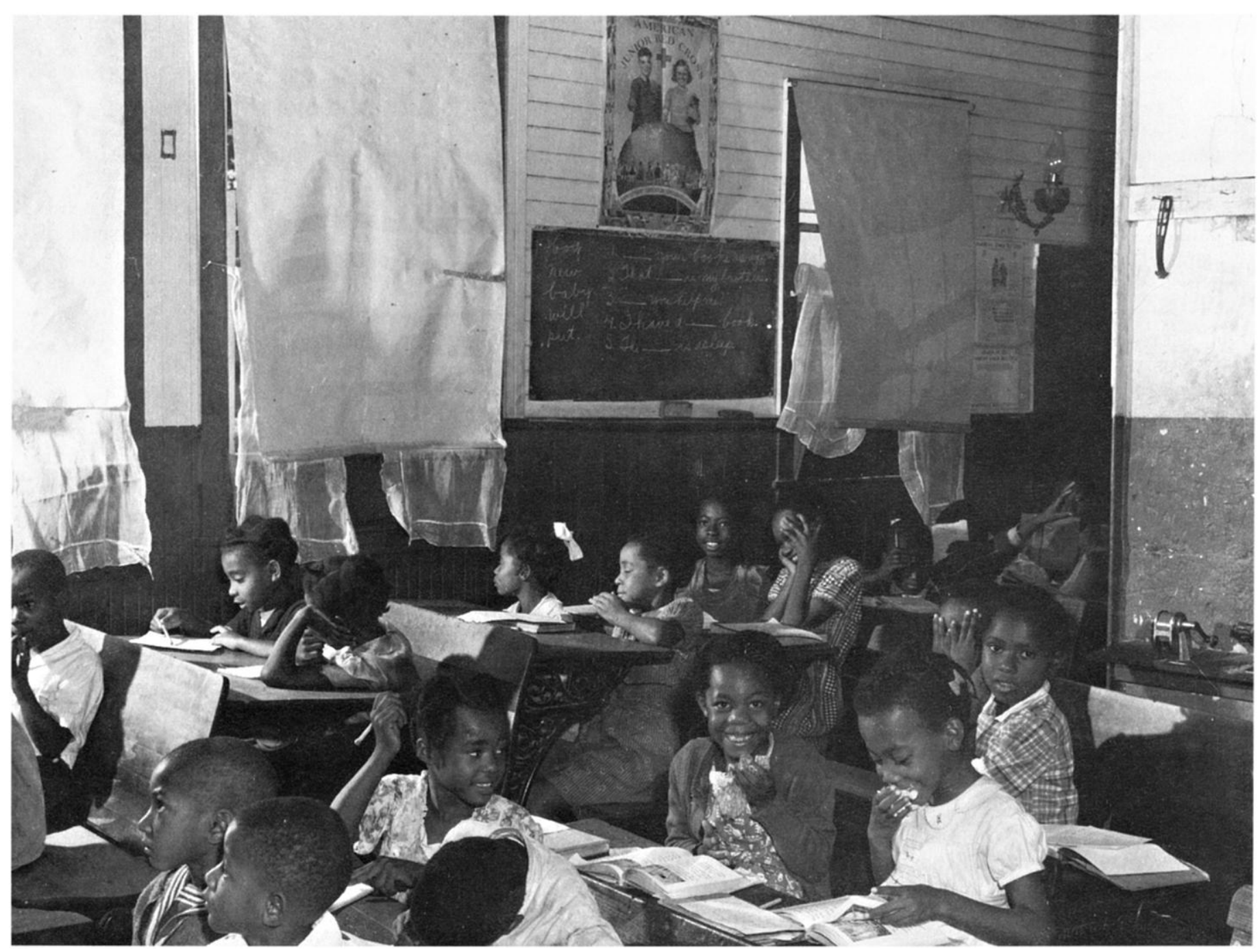

A segregated primary school, southeastern Missouri, 1938.

Courtesy of the Library of Congress 
that the [new] commissioner would mandate a forced busing program on the city of Yonkers. ... [We] therefore again recommend ... that the Board of Education reject [Superintendent] Robitaille's plan without being intimidate[d] by fear of federal or state agency sanctions [TONEY 1978]") ${ }^{7}$ The Task Force completed its report to no effect, the board closed a few schools with no attention to desegregative impact, and the superintendent resigned. ${ }^{8}$

In a similar dynamic, the Duval

\section{The absence of a threat} from an external authority makes desegregative action almost impossible.

County, Florida School Board is currently negotiating with the local NAACP over a desegregation plan. The Board is willing to search for a settlement because "if ... [it] loses [in impending litigation over being declared a unitary district] in court, such an agreement would be in place and could help dissuade a federal judge from imposing a more stringent desegregation plan" (Saunders 1996, B1).

The same point can be put negatively: the absence of a threat from an external authority makes desegregative action almost impossible. In 1987, for example, the state Commissioner of Education in Connecticut issued an "impassioned report" calling school segregation " "educationally, morally, and legally wrong.' " He called for "collective responsibility" in planning a remedy, but also suggested that the state Board of Education "be empowered to impose a mandatory desegregation plan" should the voluntary planning process fail. In the words of his later testimony, "all hell broke loose." One state legislator called for his resignation; another described him as "despicable"; the governor abjured mandatory solutions; and Commissioner Tirozzi's report of the following year never mentioned the word "desegregation" (Traub 1994). ${ }^{9}$
No school district except Hartford (with about $90 \%$ students of color) responded favorably to his call.

Most elected officials, not surprisingly, are exquisitely careful to avoid such a situation. In July 1996, only four days after the Connecticut Supreme Court ordered desegregation of the state's schools, the governor ruled out mandatory transportation: "The Supreme Court did not say they wanted forced busing, and we know that forced busing is not an alternative. It's not acceptable to the legislature, it's not acceptable to the people." Asked for an alternative proposal, he responded, "We have got to be creative and thoughtful and compassionate in figuring out other ways to try to resolve the issue ... Just because the solution is not before us at this very moment, doesn't mean it doesn't exist.... But I thought it was important to put a line in the sand and say we're not going to do forced busing because that's the issue that will ignite the emotions" (Frahm 1996).

In short, if there is to be any school desegregation beyond minimal tokenism, it almost certainly will be imposed by an authority more insulated from constituency pressures or campaign temptations than any elected official can be. That authority is usually, but need not be, a court. A few exceptions exist to this generalization, but they are either less exceptional than they initially appear to be or they are unlikely to be replicable elsewhere. Despite their abstract support for school desegregation, most white members of the American public simply do not want very many black (and disproportionately poor) children in the same classroom as their own children, and they will do what they can to keep them out. Most black members of the American public either return the compliment, or have abandoned the desegregative effort in disgust.

\section{Explaining the Variation in Consequences of School Desegregation}

It is harder to explain the array of outcomes of school desegregation
Despite their abstract

support for school

desegregation, most white

members of the American

public simply do not want

very many black (and

disproportionately poor)

children in the same

classroom as their own

children, and they will do

what they can to keep them

out. Most black members

of the American public

either return the

compliment, or have

abandoned the

desegregative effort in

disgust.

policy than to explain when and why such a policy is put into effect. I see three components as essential for a school desegregation plan to succeed: ${ }^{10}$ moral and organizational leadership, a broad mix of incentives and requirements, and contextual luck and the skill to take advantage of it.

Leadership: Ideally, leadership will come from those elected or appointed to lead-school boards and superintendents, mayors and city councils, governors and legislatorsalthough it may emerge from local notables or interest group leaders if public officials leave a vacuum. Regardless of where they come from, however, leaders must accomplish several tasks. They need not promote school desegregation; the previous section has shown that desegregation would almost never succeed if that were necessary. But once desegregation is thrust upon them, leaders do need to make the effort to turn necessity into opportunity.

Leaders can turn necessity into opportunity by using school desegregation as the excuse or lever for 
making other desirable changes in the school system. This will have the effect both of focusing attention on the school system as a whole rather than on racial tensions per se, and, if it is well done, of actually enabling the school system to improve at the same time that it is desegregating. A member of the West Hartford Board of Education opined that

the Sheff v. O'Neill challenge [the Connecticut Supreme Court desegregation mandate of July 1996] is a magnificent opportunity to design education for the 21 st century. ... Solving the issue of local integration must be a side effect, but not the sole objective of the [planning] panel. As critical a question is how the current systems are also segregating all students from participation in the global economy of the new century (Sloane 1996).

Even an entrepreneurial County Executive sees the possibility of making financial lemonade out of the desegregative lemon: "Curry is amenable to the school board's request that the court order the county and state to pay for the [newly proposed desegregation] plan.... Perhaps a court order would force other elected officials and residents in Prince George's [County] to address what Curry said is an antiquated and deficient tax structure. 'I think [the desegregation issue] certainly has tremendous implications for our current tax structure'" (Montgomery and Neal 1996).

Attaching the issue of desegregation to other school reforms raises obvious and serious risks. Those reforms themselves may generate opposition (as in Yonkers, where many parents vehemently opposed the school closings); they may take over all of the attention of school officials (as threatens to occur in the Hartford case, judging from the editorial quoted above); their failure may derail the progress of desegregation (as seems likely in Prince George's County). Nevertheless, the best evidence on thirty years of experimentation with school reform shows clearly that it is almost impossible to fix any of the parts without fixing the whole. School systems are tightly intertwined, highly complex organizations; merely moving the students or changing the funding formulas $o r$ decentralizing or reforming the cur- riculum - or any other magic bullet-runs up against the inertia and multiplicity of such a system (Hochschild 1984; Scovronick 1996; Trimble and Forsaith 1995; Payne 1997; Consortium for Policy Research in Education 1997). An educational leader who is serious about successful desegregation must seek to reform other features of his or her system simultaneously; conversely, an educational leader who seeks systemic reform may find court-ordered desegregation to be his or her best lever for achieving it.

An effective leader should do at least three other things in order to desegregate successfully. He or she needs to involve the community as much as possible while not permitting the parents with the most political resources (typically those who are white, affluent, well-educated, and/or ideologically motivated) to dominate the process. My book of over a decade ago shows what can go wrong with community participation (Hochschild 1984); here I want to emphasize what can go right. In Rochester, "community groups and community pride were the overwhelming positive forces in enabling desegregation to be effected. The riots in 1964-65 upset many community members who felt that they placed the city in a poor light. Positive action needed to be taken to remove the blot on the city's image. Wide opportunities for public discussion allowed parents and other members of the community to feel they could influence the decisions being made." A racially-mixed and middle-class Community Association, the United Federation of Inner City Parents, the Spanish Action Coalition, and the Apartment Owners Association were among the community groups that participated in designing the Rochester plan. In Dayton,

providing opportunities for community involvement in the implementation of the various desegregation plans received at least as much attention as the creation of the plans themselves. The literature prepared by the Superintendent's office emphasized the importance of community input. Advisory boards, which met every Saturday, were created that included business and religious leaders, social agencies and the police, parents and other grass roots groups. The murder of court monitor Charles Glatt, by an irate white citizen opposed to desegregation, shocked the community and served as a compelling impetus for people to work together.... The community groups and community participation in general was extremely important in implementing the desegregation efforts (Stave 1995).

These are not ideal models; if a riot or murder is needed to bring a community together to plan for an undesired but inevitable change in social policy, community participation is hardly an unalloyed good. Nevertheless, school desegregation mandates are much more likely to succeed if they are taken up by leaders who impel the community toward a sense of responsibility for the collective outcome.

Effective leadership is, thirdly, moral. Educators (and hopefully elected officials) need to emphasize the desirability for all races of ending racial isolation, the importance of education for the whole community, the role of public schools as a unifying and edifying institution, and the virtues of innovation. These arguments need to be made repeatedly, forcefully, eloquently, and persuasively-and they need to be backed up by the other actions described herein. This requirement is as easy to describe as it is hard to do. But the evidence from arenas ranging from the abolition of sexual harassment in corporations to the willingness of agency officials to convey bad news to their chiefs is clear. Leaders can set the tone of their organization's behavior by (1) issuing clear statements of expectations, backed by (2) clear channels for reward and punishment based on those expectations, and (3) ensuring widespread publication of those rewards or punishments and the reasons thereof. Employees are usually willing to comply with actions that both are fair by the stated criteria, and are seen to be fair, even if the criteria themselves are not ones the employees would have chosen.

That sentence suggests the fourth requirement of leadership; leaders must be prepared to amass the power to enforce unpopular orders and then to issue those orders if 
necessary. Here is another way in which a judicial or administrative order provides some of the ammunition to do what it requires; if a school superintendent can persuasively argue that the court will issue an even more unpalatable order if the current one is not obeyed, he or she has considerable leverage to add to the power inherent in the position of superintendent.

Incentives and Requirements: Moral, forceful, imaginative, and sensitive leadership is necessary but not sufficient to achieve success in a social policy as fraught with political and substantive difficulties as school desegregation. Good policies are equally essential. Good policies, we have discovered after thirty years of experimentation with school desegregation, are at base an effective mix of incentives and costs. The plan needs incentives in order not to lose reluctant or fearful participants who have other options. It also needs to impose costs on those same participants because in order to succeed, school desegregation must redistribute at least some money, power, status, and comfort beyond what people will voluntarily redistribute.
To assert that school desegregation needs the right combination of incentives and costs in order to succeed remains merely a cliché until it is given precise content. Unfortunately, that is very difficult to do in the abstract; particular districts have different geographic, demographic, economic, political, and characterological configurations that must be taken into account in designing a plan. A few general findings, however, can at least point us in the right direction.

First, few whites, and increasingly fewer blacks, will tolerate transfers of students merely in order to balance the races in schools or classrooms. The reasons are various, including but not limited to racial hostility. Regardless of preferences, however, racial balance is a necessary first step in successful school desegregation, so a way must be found to attain more of it. Several educational techniques are relatively effective in persuading parents to send their children to a public school other than the one they would initially prefer (usually but not always a neighborhood school). Those techniques include (1) sub- ject-specific magnet schools for middle and high schools and pedagogically distinct magnet schools for the elementary grades; (2) districtwide-or better, interdistrictchoice among a variety of schools coupled with extensive and sophisticated dissemination of information; (3) physical renovation of schools and the addition of special equipment such as computer or science labs; (4) dramatically lowering the student/teacher ratio; (5) safe and convenient transportation, a safe school, and a safe environment around the school; (6) connecting the school with a prestigious external organization such as a university or corporate employer; and (7) enhancing the quality and quantity of extracurricular activities and "specials" such as art and music instruction during regular school hours. Other techniques could be added to the list, but all have the same basic characteristic-they offset the "cost" of sending one's child to a school with a nonpreferred racial balance with incentives designed to improve the educational outcomes and daily enjoyment of public schooling. (Note that these techniques are not in

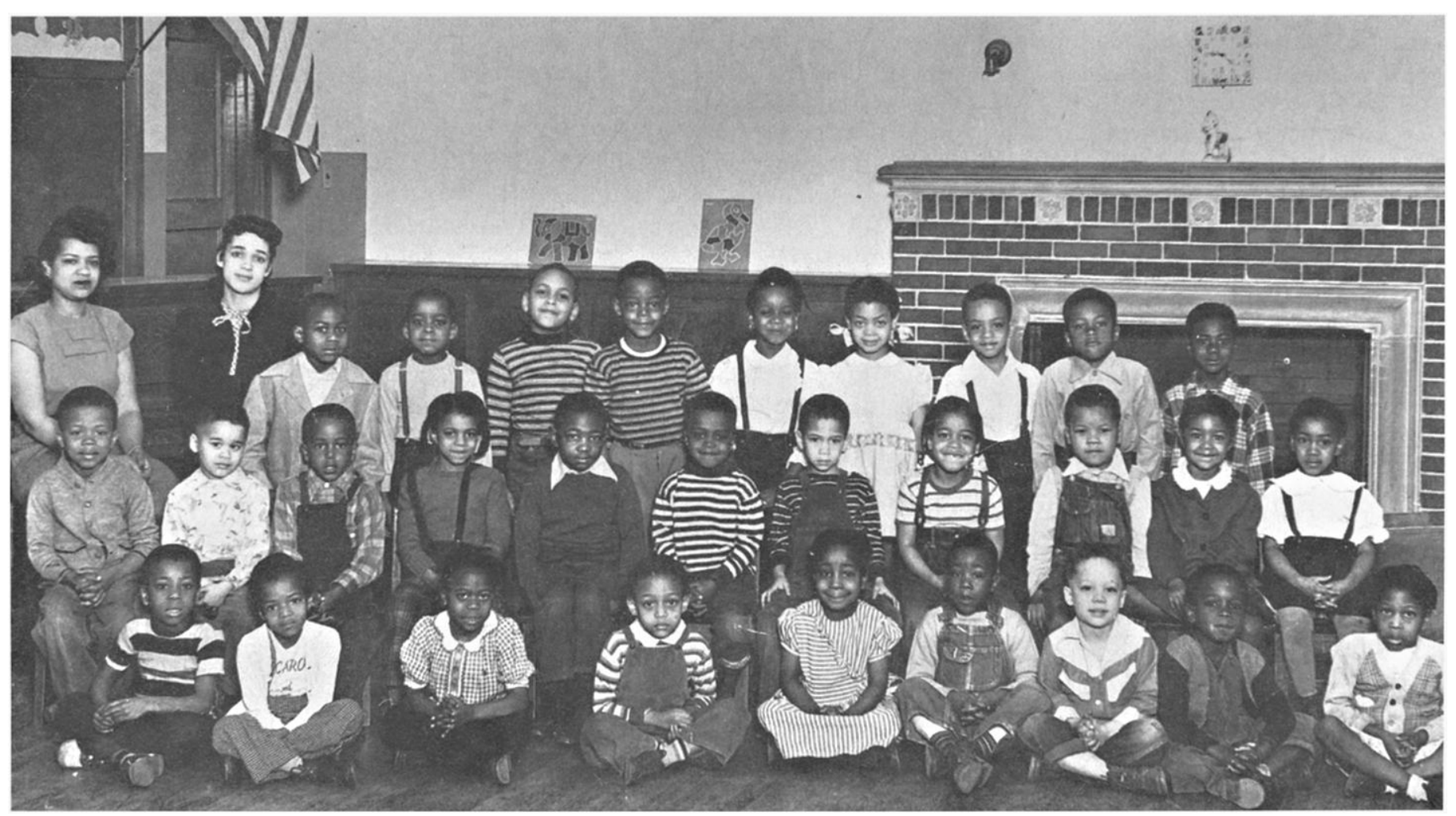

Kindergarten class, 1949, of Linda Brown (back row, fourth from the right), daughter of plantiff in Brown v. Board of Education of Topeka, Kansas, 1954. Courtesy of the Topeka Capital-Joumal, Topeka, Kansas. 
most cases alternatives; many are, in fact, interactive, such that combinations of reforms will have much more impact than one or two isolated reforms. This is, of course, another way of making the point that desegregation is most effective when combined with systemic school reform.)

Another strategy for creating incentives to balance the presumed costs of desegregation focuses less on the content of schooling and more on changing the organizational and governance structure of the schools. The key idea here is control, coupled with choice. If parents perceive that they have some control over which school their child attends and what happens within the school, they become more willing to participate in a desegregation plan. Thus, in Rochester, "once the magnet concept was made the cornerstone of the desegregation efforts, parents felt they had choice and control over the destinies of their children and support for the desegregation concept grew." Similarly in Dayton, "parents' feeling they had some control over the destiny of their children was the most important factor in enabling desegregation to take place" (Stave 1995, 41, 21). Dayton now combines magnet schools with an increasing emphasis on site-based management and decentralized administration.

Looking across a variety of school districts, most researchers now claim that controlled choice plans produce more racial balance than does mandatory reassignment (Rossell 1990; Armor 1995), or even that purely voluntary plans produce more racial balance than controlled choice plans (Rossell 1995, 43-76; but see Orfield, Eaton, et al. 1996). Others have demonstrated that decentralization of curriculum, budgetary, and personnel decisions to the parents and staff of individual schools can in some cases improve the quality of education and the willingness of parents to send their children to a previously disfavored school (Bryk et al. 1993).

Contextual Constraints and Possibilities: A final rule for successful school desegregation is: be aware of constraints and possibilities given by context. There is even less generalizable policy wisdom here than with

\section{If parents perceive that they} have some control over which school their child attends and what happens within the school, they become more willing to participate in a desegregation plan.

the second rule (about costs and incentives), since context is by definition idiosyncratic to specific places. So here I must rest content with the simple point that policy-makers must be sensitive to context without allowing it to stifle innovation.

Some contexts are especially difficult to negotiate from the perspective of implementing school desegregation. Examples include a state comprised of many small districts with a fierce sense of local autonomy (New Jersey), districts that are extremely large physically (Los Angeles) or in population (New York City), districts with terrain that makes movement difficult (Los Angeles, Yonkers), districts with a history of robust racial or ethnic antagonism (Boston, Chicago), and districts with a history of corruption and malfeasance in school board members and administrators (New York City, Newark). These are the places where school desegregation has not occurred or where its implementation has ranged from ineffective to disastrous.

But other contexts provide an opportunity for policy innovation. They include communities with an unusually liberal population (Princeton, Berkeley, Madison, WI), communities whose self-image importantly depends on the absence of racial hostility (Rochester, Atlanta), districts that encompass suburbs and rural areas as well as city (most southern districts and Hawaii), and districts with a relatively small black population and/or a relatively affluent population of other non-Anglos (Seattle, Tacoma). These are the places where school desegregation has been on balance peaceful, voluntary, persistent, and successful.

We hear much more about the disasters than about the successes. The former make better news stories, they involve more people on any one occasion, and they typically occur near or in media centers. But over many years and across the full expanse of the nation, there are arguably more people in potentially favorable than in probably hostile contexts. Policy makers need to be alert for circumstances that will encourage desegregation, and need equally to be prepared to do what they can to offset the circumstances that will discourage it.

These four lessons about how to desegregate successfully are difficult to articulate, and even more difficult to implement-no wonder school desegregation can hardly be described as a stunning success. So why bother?

\section{Conclusion: School Desegregation Is the Worst Option, Except for the Others}

Winston Churchill described democracy as the worst system of governance except for all of the others. School desegregation is similar: few people want it, most districts do it poorly-but, when coupled with deep systemic reform of educational governance and content, it is our only available option for ending the racial isolation and (possibly increasing) racial antagonism that separates cities and suburbs. Racial separatism is neither, in my view, a viable option for most African Americans nor an attractive one for most whites. At best, it is unstable and personally constricting; at worst, it is a recipe for increased tension, hatred, and eventual violence. Nor will racial integration develop on its own at a pace faster than all deliberate speed. We cannot afford to wait for the infinitesmally slow process of residential desegregation or racial intermarriage to dissolve black-white hostilities. Racial integration in the workplace is reasonably effective, but it requires that young adults be sufficiently well-educated to be able to get a job in the first place. 
And that leads to my final argument for school desegregation. We cannot afford to allow urban school systems to continue to deteriorate. There are 1,500 fourth graders in Hartford who attend schools where fewer than $1 \%$ of the children meet the state math and reading goals for their grade level. Putting them on a bus to Guilford will not by itself

\section{There are 1,500 fourth graders in Hartford who attend schools where fewer than $1 \%$ of the children meet the state math and reading goals for their grade level.}

teach them how to read, but neither-demonstrably-will leaving them where they are. Ensuring that they attend a school where other children can read and add is, according to the scattered but consistent evidence, their best chance to become literate adults. Conversely, putting some of Guilford's children on a bus into Hartford-assuming that they would go-would perhaps galvanize the Hartford school district and state of Connecticut into taking the painful and expensive steps needed to blow up this nonfunctional system. Perhaps no individuals are at fault, and certainly many individuals make heroic efforts to teach children in inner city schools, but for whatever complicated set of reasons the results are simply unacceptable. In that context, even a little success in desegregating schools is worth pursuing.

\section{Notes}

1. In $1972-73,64 \%$ of black children and $57 \%$ of Latino children attended predominantly minority schools; in 1994-95, the figures had increased to $67 \%$ and $74 \%$, respectively (Orfield, Bachmeier, James, and Eitle 1997, 11).

2. In a series of focus groups about the
Court ruling, "few parents, students, or educators believed that racial isolation was the main contributor to the poor performance of Hartford students. All the groups ... felt that the primary focus should be on improving the educational system in the Hartford school system rather than focusing on objectives such as busing or redistricting." (Darryl McMiller, message to Race-Politics Listserv, 13 November 1996.) Perhaps the main lesson here is that people will respond very differently depending on what alternatives are offered to them. If the choice is real compliance versus superficial pretense, they opt for the former; if the choice is desegregation or the possibility of some other (unspecified?) reform that will improve children's achievement, they opt for the latter. It is also possible that focus groups elicit different views from surveys, but I see no reason at present to believe that one form of response is necessarily more trustworthy than the other.

3. I developed this argument in (1984, chap. 5).

4. Which made it almost impossible to impose mandatory interdistrict remedies.

5. Which held that once a district met the requirements of good faith compliance and elimination of vestiges of segregation, it could be declared unitary. In that case, it was released from its obligation to maintain a mandatory busing plan and racial balance plan.

6 . Which ruled that financial equalization remedies that substituted for physical desegregation could be limited in time and extent, and that school districts need not improve educational outcomes in order to be declared unitary on other grounds.

7. Taxpayers Organization of North East Yonkers Education Committee, TONEY Report on School Reorganization Phase \#2 (Printed in the Herald Statesman), 5 March 1978: 1-1d. The Lincoln Park Taxpayers issued a similar memo in 1997 (Lincoln Park Taxpayers Association Education Committee, Report (Unpublished manuscript, 1977).

8. Two years later, the NAACP and U.S. Justice Department took the Yonkers Board of Education to court in a desegregation suit. The Yonkers School District was found guilty of de jure segregation in 1985.

9. Five years later, in the face of a lawsuit demanding mandatory desegregation of Hartford and the surrounding suburbs, the Connecticut legislature set up eleven regional planning groups across the state to propose means to voluntarily desegregate the schools. (The enabling legislation, however, neither included numerical goals nor mentioned the word "desegregation.") After six months of deliberation, "every region endorsed using interactive video among schools" and a few proposed new magnet schools-five in all, for a state with 508,000 public school students, and even then only if new state funds were forthcoming to pay for them. After all, as the chair of Glastonbury's Town Council pointed out, "towns are willing to put up a certain amount, but we still have our taxpayers to account to, and our kids" (Judson 1994).

10. I define success in school desegregation broadly and eclectically. It includes interracial exposure, the maintenance of academic achievement for the highest-achieving students and gains in achievement for the lowest- achieving students, a level of social comfort that involves routine interactions if not close friendships across the races, a racially mixed teaching and administrative staff, and good school morale. Many other features are equally desirable, and may be necessary to achieve those just listed. They include broad parental participation in the schools, mainstreaming special education students as much as possible, ensuring the needed social and health services for students, enabling successful transitions into employment or higher education, and fostering a multicultural curriculum and experiential pedagogical techniques.

\section{References}

Armor, D. 1995. Forced Justice: School Desegregation and Law. New York: Oxford University.

Blank, R. et al. 1983. Surveys of Magnet Schools. Cambridge, MA: Abt Associates.

Byrk, A., et al. 1993. A View from the Elementary Schools: The State of Reform in Chicago. Chicago: Consortium on Chicago Schools Research.

Clough, R., and S. Utchitelle. 1995. Complete Twelfth Report to the U.S. District Court, Eastern District of Missouri. Voluntary Interdistrict Coordinating Council for the Settlement Agreement.

Consortium for Policy Research in Education. 1997. Public Policy and School Reform: A Research Summary. University of Pennsylvania, Graduate School of Education.

Cooperative Institutional Research Program. 1991. The American Freshman: Twenty-Five Year Trends. Los Angeles: UCLA, Graduate School of Education.

Cooperative Institutional Research Program. 1992. The American Freshman: National Norms for Fall 1992. Los Angeles: UCLA, Graduate School of Education.

Edmonds, Patricia. 1994. "Only Difference: How Best to Desegregate," USA Today. 12 May.

Frahm, R. 1994. "Q and A with the Governor," Hartford Courant. 14 July: A4.

Frahm, R. 1996. "Residents as Divided as Court on Sheff," Hartford Courant. 16 August.

Harris, L., and Associates. 1978. A Study of Attitudes Toward Racial and Religious Minorities and Toward Women. New York: Louis Harris and Associates.

- 1989. The Unfinished Agenda on Race in America, vol 1. New York: Louis Harris and Associates.

Hochschild, J. 1984. The New American Dilemma: Liberal Democracy and School Desegregation. New Haven: Yale University Press.

Judson, G. 1994. "Integration by Choice: Connecticut Struggles," New York Times. 7 October: A4.

Libov, C. 1996. "Racial Report on Schools: The Fallout." New York Times 31 January II CN.

Lincoln Park Taxpayers Association Education Committee. 1977. "Report." Unpublished manuscript.

Lissitz, R. 1994. Assessment of Student Performance and Attitude, Year IV-1994. Report 
submitted to the Voluntary Interdistrict Coordinating Council, St. Louis.

Montgomery, D., and T. Neal. 1996. "In P.G., a New School of Thought," Washington Post. 28 July.

National Institute of Education. 1978. Violent Schools, Safe Schools. Washington, DC: U.S. Government Printing Office.

Orfield, G., M. Bachmeier, D. James, and T. Eitle. 1997. "Deepening Segregation in American Public Schools." Cambridge, MA: Harvard University School of Education.

Orfield, G., S. Eaton, et al. 1996. Dismantling Desegregation: A Quiet Reversal of Brown v Board of Education. New York: The New Press.

Payne, C. 1997. “'I Don't Want Your Nasty Pot of Gold': Urban School Climate Revisited." Chicago: Northwestern University, Department of Sociology.
Rossell, C. 1990. The Carrot or the Stick for School Desegregation Policy. Philadelphia: Temple University Press.

Rossell, C. 1995. "Controlled-Choice Desegregation Plans: Not Enough Choice, Too Much Control?" Urban Affairs Review 31(1): 43-76.

Saunders, J. 1996. "Court Still Looms for School Dispute.” Florida Times-Union. 11 August.

Scovronick, N. 1996. "Education Policy and Politics." Princeton: Princeton University, Woodrow Wilson School of Public Affairs.

Sloane, W. 1996. "Sheff Decision is Opportunity to Reinvent the School System," Hartford Courant. 2 September.

Stave, S. 1995. Achieving Racial Balance: Case Studies of Contemporary School Desegregation. Westport, CT: Greenwood Press.
Traub, J. 1994. "Can Separate be Equal?" Harper's Magazine. June.

Trimble, C.S., and A. Forsaith. 1995. "Achieving Equality and Excellence in Kentucky Education." University of Michigan Journal of Law Reform 28(3): 599-653.

Taxpayers Organization of North East Yonkers Educational Committee. 1978. TONEY Report on School Reorganization Phase \#2 Printed in the Herald Statesman, 5 March.

\section{About the Author}

Jennifer Hochschild is professor of politics and public affairs at Princeton University.

\title{
Reaching Beyond Race
}

\author{
Paul M. Sniderman, Stanford University \\ Edward G. Carmines, Indiana University
}

$\mathbf{F}$ ifty years ago, the cross was taken up again on behalf of racial equality. Success may seem to have been assured, but only in retrospect. Initiated by Southern blacks, reinforced by volunteer whites from the North, and transformed by the charismatic leadership of Martin Luther King Jr., the civil rights movement put an end to state-mandated segregation, an historic accomplishment ratified into law in the 1964 Civil Rights Act and the 1965 Voting Rights Act.

The achievement of equality under the law was a monumental victory. But legal equality did not, as the passing years have made plain, automatically translate into economic or social equality. Of course, there have been gains. For one, the black middle class has at least tripled in size, not a small advance by the standards of actual rather than ideal societies. Yet, for all their progress, blacks remain poorer and die younger, to mention only two of the persisting expressions of racial inequality. Notwithstanding the historic injustices that black Americans have suffered, large numbers of white Americans remain opposed to a wide array of public policies, from social welfare through affirmative action, aimed at finally achieving racial equality. Indeed, it does not exaggerate to say that the politics of race has been at an impasse for at least a decade, with racial liberals investing their energies mainly in a defensive struggle to hang on to the gains of the 1960s and 70s.

Why the stalemate? When we began our work, it was generally

\section{The politics of race has} been at an impasse for at least a decade, with racial liberals investing their energies mainly in a defensive struggle to hang on to the gains of the 1960s and 70s.

agreed that the clash over race centered on racial prejudice. Racial bigotry, to be sure, was variously conceived. Some, following established conceptions of prejudice, saw it as centered on aversion to blacks; others, taking up new approaches, saw it as a witches' brew, blending racial prejudice and commitment to traditional American values, above all, individualism. But in either case, the claim is that the most important force shaping the attitudes of white Americans about issues of race is racial prejudice.

Both of us agreed that prejudice still mattered, but working independently, we each became persuaded that a still more important factor was in play. Racial politics was not autonomous. The contemporary conflict over racial policy owes its essential shape to the fundamental structure of American politics, and a key component of the structure of conflict in American politics is ideology. The argument over race has its own, uniquely bitter bite, but it was, in the end, caught up in the larger argument, running through American politics as a whole since at least the Great Depression, between liberals and conservatives over the responsibilities of government and the duties of citizens.

Or so we saw it when we started our work together. Yet the deeper we waded in the waters of our joint research project, the less certain we were of our own footing. The politics of race in the 1980s and 90s 